\title{
Factors Affecting Livelihood Diversification Decision: The Case of Kuormuk and Homosha Districts of Assosa Zone, Beneshangul Gumuz Regional State, Ethiopia
}

\author{
Amente Negussa Bayata ${ }^{1}$, Tewodros Adane Nega ${ }^{2}$ \\ ${ }^{1}$ Department of Agricultural Economics, Assosa University, Assosa, Ethiopia \\ ${ }^{2}$ Department of Agricultural Economics, Debark University, Gonder, Ethiopia \\ Email address: \\ amentnug@gmail.com (A. N. Bayata), teddyadane222@gmail.com (T. A. Nega) \\ To cite this article: \\ Amente Negussa Bayata, Tewodros Adane Nega. Factors Affecting Livelihood Diversification Decision: The Case of Kuormuk and \\ Homosha Districts of Assosa Zone, Beneshangul Gumuz Regional State, Ethiopia. American Journal of Plant Biology. \\ Vol. 5, No. 4, 2020, pp. 68-76. doi: 10.11648/j.ajpb.20200503.16
}

Received: September 4, 2020; Accepted: September 19, 2020; Published: November 23, 2020

\begin{abstract}
Ethiopia's agricultural productivity is considered low despite the presence of various agricultural policies. These policies focus mainly on on-farm agricultural development to the neglect of rich opportunities for non-agricultural livelihood diversification activities. Livelihood diversification is a strategy that can boost farmers' income and promote sustainable land management practices. This study was conducted to assess the various factors that affect households' decisions on livelihood diversifications the case of Kuormuk and Homosha districts of Assosa zone, Beneshangul Gumuz regional state, western Ethiopia. Data was gathered by household survey from 376 sample households of 13 randomly selected rural kebeles of the Homosha and Kuormuk Districts through structural questionnaires. The alternative livelihood strategies that were used by the study households were agriculture only, and agriculture plus other activities (off-farm and non-farm activities). Binary Logit model was employed in identifying the determinants of rural livelihood diversification decision. From 13 hypothesized explanatory variables, 5 variables were found to have significant effect in determining diversification of household livelihood decisions. Accordingly, age of the household head, access to credit, receiving remittance and land size have negative association with livelihood diversification strategy. Whereas, getting training has a positively influence on households choice of livelihood diversification. Therefore, the findings of this imply that rural households' development policies should consider off-farm and non-farm livelihood activities in addition to agriculture.
\end{abstract}

Keywords: Livelihood, Diversification, Binary Logit Regression, Ethiopia

\section{Introduction}

\subsection{Background}

Ethiopian agriculture accounts about 42 percent of the GDP, employs about 85 percent of the employment. The central Statistical Agency has been conducting and providing agricultural statistical census by the year 2001/02 and has planned to conduct the second one by 2018/19 [1].

The agricultural sector plays an important role in the national economy, livelihood and socio-cultural system of the country. The sector supports employment of over $80 \%$ of the population and accounts for 45 to $50 \%$ of the national GDP. Diversification of income sources, assets, and occupations is the norm for individuals or households in different economies, but for different reasons [2].

Livelihood diversification is classified in various ways by several scholars. Scholars identified four distinct rural livelihood strategies contributing noticeably different returns and distributions. Some rural households depend exclusively on their own agricultural production for income, what they define the "full-time farmer" strategy. Others combine own production on-farm with wage labor on others' farm, which they refer to as the "farmer and farm worker" strategy. The third strategy combine farm and non-farm returns. The fourth "mixed" strategy combines all three basic elements discussed so far: on-farm agricultural production, unskilled on-farm or off-farm wage employment, and non-farm returns from 
trades, commerce and skilled (often salaried) employment The scholars also grouped the components of rural livelihood diversification by sector (farm or non-farm), by function (wage employment or self-employment) or by location (onfarm or off-farm) [3].

In Ethiopia at national, regional and household levels the focus of policy is to increase agricultural productivity and farm income so as to attain food self-sufficiency. Although, substantial resources have been spent on agricultural research and extension to alleviate food shortage in the nation, research and extension activities have not been done adequately on the issues related to off or non-farm employment. In spite of this fact, farmers are engaged in a variety of off and/or non-farm activities to diversify their income with a view to feed and sustain themselves during crop failures [4]. Moreover, the contribution made by livelihood diversification to rural livelihoods is significant and has often been ignored by policy makers who have chosen to focus their activities on agriculture [5].

Thus, a thorough understanding of alternative livelihood strategies of rural households and communities is indispensable in any attempt to bring improvement. This is important not to commit a limited resource available for rural development based on untested assumption about the rural poor and its livelihood strategies [6].

\subsection{Statement of the Problem}

A significant number of farm households in sub-Saharan Africa especially in Ethiopia, rely on natural rainfall for their farming activities and are worst affected by changes in weather patterns [7]. Commonly cited adaptation strategies and measures to improve food security include farm management and technology, diversification on and beyond the farm and government interventions in rural infrastructure [8].

The available empirical evidences indicate that there is a wide difference between results concerning the share of non/off-farm income in total household income in Ethiopia. The non/off-farm contribution in 1989/90 for rural income in Ethiopia was on averaged about $36 \%$. In contrast, it was found that non/off-farm share of total income in rural Ethiopia was about 20\% [9].

Off course, many researchers conducted research to see the determinants of rural diversifications carried out research on livelihood diversification in Borana pastoral communities of Ethiopia prospects and challenges. However, the focus of their work was on the strategies of improving sustainable livelihoods and reducing vulnerability to disasters of the pastoral communities in Ethiopia [10]. Researches are conducted on the determinants and impacts of income diversification at the regional level of SNNPR, which was not at specific area and agro-ecology. However, in both study district livelihood diversification has been practiced over time. There are numerous factors that determine rural households' ability to diversify their livelihood strategies away from crop and livestock production into off- and nonfarm economic activities [11]. And also a fairly comprehensive search of literatures showed no research on this particular issue has been conducted in the selected study sites so far. As a result of this, it is necessary to assess what livelihood strategies are adopted by farm households and what factors affect farm household decisions' on diversifying livelihood activities to raise their income in particular contextual area of the study Districts.

\subsection{Objective of the Study}

\subsubsection{General Objective}

The overall objective of this study was to assess factors that affect farmers' decisions on livelihood diversifications.

\subsubsection{Specific Objectives}

To investigate the common means of livelihood beyond Agriculture (on farm) activities in the study area.

To identify the major driving forces why rural households engage in livelihood diversification activities besides farming in the study area.

\section{Methodology}

\subsection{Description of the Study Area}

The study was conduct in Kuormuk and Homosha district of benishan gulgumez region of Ethiopia, part of the Assosa zone. Geographically, Kuormuk has latitude and longitude of $1032 \mathrm{~N} 3417 \mathrm{E} / 10.533 \mathrm{~N} 34.283 \mathrm{E}$ with an elevation of 653 meters above sea level (BoA, 2011). It is bordered by Sudan in the north and west, sherkole in the east, Homosha in the south east, and Assosa in the south.

The total population for kumoruk district is 26,600 of whom 14,700 where men and 11,300 where women, 553 or $3.31 \%$ of population where urban dwellers [12]. The livelihood of the rural part of the kumoruk district is mainly based on agriculture and traditional gold mining. Rural household in the district continue to struggle with food insecurity primary cause by extreme drought. The mean annual rain fall ranges from 700-1000 meters above sea level \& $800 \mathrm{~mm}-900 \mathrm{~mm}$ respectively. Its temperature also varies ranges from $26^{\circ} \mathrm{C}-35^{\circ} \mathrm{C}$. Besides this information, the main agro-climatical zones of this district were dry kola which covers $85 \%$ of the total area, moisture kola which covers $15 \%$ of the total area [13].

Similarly, these studies were conducted in Homosha, district Assosa zone of Benishangul Gumuz Regional State. Homosha is bordered by the Assosa in the south, komuruk on the North West and Menge on the east located in the western part of Assosa Zone. Sherkole refugee camp housing 9,526 displaced people from Sudan and south Sudan, it also located in Homesha. It is located $697 \mathrm{~km}$ away from Addis Ababa, the capital city of Ethiopia. It is one of the seven districts found in Assosa zone.

The total population for Homosha district is 21,755 of whom 11,685 where men and 10,070 where women. The livelihood of the rural part of the Homosha district is mainly based on agriculture and fruit [14].

Based on data obtained from Homosha agricultural office 
(2018), the mean annual rainfall in the study area is about $1700 \mathrm{~mm}$. The mean annual temperature is about $36^{\circ} \mathrm{C}$ and the mean minimum temperature is $21^{\circ} \mathrm{C}$ whereas the mean maximum temperature is $28.5^{\circ} \mathrm{C}$.

The data required from the district office of agriculture indicated that Its altitude range from 1040 meter above sea level, The current land use land cover types of the District comprises of cultivated (arable) land which cover the largest proportion of the area about 15,000 ha, grazing land 20,00 ha, bush/shrub land 32,256 ha, forest and grass land 16,000 ha and village and construction 4788 of the total area of the districts.

\subsection{Research Approach and Methods}

This research used both primary and secondary data to analyze the factors affecting livelihood diversification decision. It could be filed research from targeted group through direct contact for primary data sources and also analysis of different articles, books, unpublished official reports and other related documents in order to understand the case through secondary sources. This research approach designed in a descriptive survey with cross sectional and observational studies. Both qualitative and quantitative data types were in combination applied to support each other in different level of the research.

\subsubsection{Research Design}

The process of the research starts with defining research problem, research objective and questions, identification of the required data and data collection. On the bases of these, analysis and discussions was made and drew same sort of conclusions and recommendations. The overall research design is illustrated in the figure below.

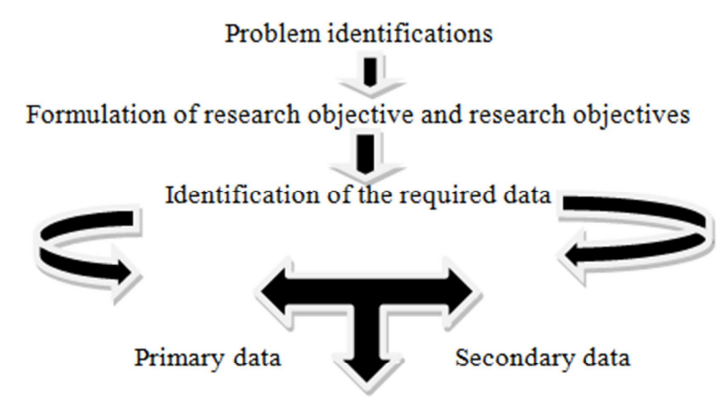

Identification of the factors affecting livelihood diversification decision

Conclusions and recommendations

Figure 1. Research Design.

\subsubsection{Data Source and Data Collection Methods}

To acquire relevant qualitative and quantitative data for this study, both primary and secondary sources were used. Secondary data were obtained from literature both scientific and non- scientific reports, published and unpublished materials from CSA, bureau of agriculture and natural resources. Data from secondary sources were used in order to supplement the qualitative result from structured questionnaire.
Primary data sources were collecting by using combination of methods such as structured interview through close ended and response option interview questions, focus group discussion, formal and informal interviews (key informants) and field observations.

All the necessary detailed information about the factors affecting livelihood diversification decision has been collected from sample household farmers of each kebele through a farm household survey. At the first stage of the survey, an informal meeting with key informants (farmers, elders peoples, and development agents (DAS) was held to gain in depth knowledge and understand general agriculture and socio economic situations of the study areas.

The translated questionnaire was first pretested with 15 farmers so as to make it comprehensive before the full execution of the interview process. The questionnaire was amended by the feedback obtained after the pretest.

To build up the respondents trust, the enumerators was informed to each household heads about the purpose of the survey and why she/he was chose for the interview. Four (13) enumerators /interviewers/ were selected based on their proficiency on the local setting and understanding of the subject matter. One day of intensive training on how to conduct interview and recording information in the questioners were given by the researcher. At the end of the formal survey in each kebeles, discussions were held by the researcher and the four (13) enumerators.

Focus group discussion: three focus group discussions had taken place for this study with community elders and district experts to gather qualitative data and to get an in depth information about the overall livelihood diversification process. Key informants interview: key informant research instrument is crucial to clearly understand the livelihood diversification decision of the community. Therefore, for the key informant (KI) interview, individuals who have had better knowledge of the case understudy include KIs were model farmers, development agents, and others.

Moreover, researcher own observations (transect walk) of the sites was used to understand the overall livelihood diversification strategies to cross-check data generated through household survey and key informants.

\subsubsection{Sampling Technique and Sample Size Determination}

In this study, multi-stage sampling method was used to select the samples. In the first stage, out of the 7 districts found in Assosa Zone, two districts (namely, Homosha and Komurk) districts were selected purposively. The two districts was considered as a sample districts because of its more food insecure area compared to other woreds and, the different factors affecting livelihood diversification in the area is not studied. In the second stage, a total of 13 kebeles were selected randomly from the two districts. At the third stage, from the selected rural kebeles sample households was determined by using the sampling techniques method simplified by Cochran in 1977. Following this, about 376 sample households were taken as sample for the household survey residing in 13 rural kebeles. Lastly, representative 
samples were selected randomly from sampled kebeles based on proportional to sample size [15].

\subsection{Method of Data Analysis}

The data generated from primary and secondary sources were analyzed and interpreted quantitatively and qualitatively by using both descriptive and inferential statistic as well as econometric tool through binary logistic regression.

Variables and working hypothesis

Table 1. Descriptions of all explanatory variables used in the model.

\begin{tabular}{ll}
\hline Variables name & Descriptions \\
\hline Livelihood diversifications decision & $\begin{array}{l}\text { A dependent variable measuring whether a given livelihood activities beyond agriculture } 1 \text { if they are diversified } \\
\text { household, } 0 \text { otherwise. }\end{array}$ \\
Age & Age of the household head in year \\
Sex & Sex of the household head; dummy ( 1 if male; $0=$ female) \\
Education & Education of the Household head dummy $(1$ if literate; $0=$ illiterate) \\
Family size & The family size of household head. \\
EAFM & economically active family members (EAFM) were $>14$ and $<65$ \\
Distance to district market & Average distance of a market from residence (in walking minutes) \\
Livestock & Livestock holdings of the household in TLU \\
Land & Total land area of a household owned in hectare \\
DA visit & Dummy, 1 if household getting extension service, 0 otherwise \\
Advise/ training & Dummy, 1 if household getting advice/ training, 0 otherwise \\
Credit & Dummy, 1 if household used credit, 0 otherwise \\
Remittance & Dummy, 1 if households received remittance; 0 otherwise \\
Cooperative & Participation of the household in cooperatives 1 if households participate; 0 otherwise \\
\hline
\end{tabular}

\section{Results and Discussions}

\subsection{Characteristics of Respondents}

The pooled average age of the respondent household head of the two study area is 48 years. The mean age of the household head of Kuormuk was 47 years and the mean age of the household head of Homosha district is 49 years (Table 2). Most of the household heads were between the ages of 41 to $60(70 \%)$. This is one of the household characteristics that are important to describe the households working age (productive age). This is supported by review report on the average age of the household heads in the in Ethiopian smallholder farmers are ranged from 39.7 to 51.9 years, and it is within the range of the productive age. Also the majority of respondents are adult, though a great deal of the youth is still engaged in the diversification [16].

The mean family size of the household head in Kuormuk and Homosha districts is 6.46 and 5.65 persons, respectively. The pooled average household family size of respondents was 6 persons (Table 2).

The minimum and maximum livestock holding in TLU for the respondents was 0.00 and 14.90 respectively with the mean livestock holding in TLU of 3.9163 and standard deviation of 2.52417 .

The average land holding size (rent, own and your family land) of Kuormuk and Homosha districts of sampled household heads are 1.2 ha and 1.1 ha, respectively this is including the (Table 2).

Average distance of market from home in Kuormuk and Homosha district is 7.7 and $6 \mathrm{~km}$, respectively (Table 2). Distance to market influences livelihood diversification decision due to perishability nature of the product. The closer to the market the lesser would be the transportation cost and time spent.

Table 2. Household characteristics in Kumruk and Homosha districts.

\begin{tabular}{|c|c|c|c|c|c|c|c|c|c|}
\hline \multirow{2}{*}{ Variables } & \multicolumn{3}{|c|}{ Kuormuk } & \multicolumn{3}{|c|}{ Homosha } & \multicolumn{3}{|c|}{ Total } \\
\hline & $\mathbf{N}$ & Mean & SD & $\mathbf{N}$ & Mean & SD & $\mathbf{N}$ & Mean & SD \\
\hline Age (Years) & 202 & 47.4 & 8.5 & 174 & 49 & & 376 & 48 & 8 \\
\hline Family size & 202 & 6.46 & 1.7 & 174 & 5.65 & & 376 & 6.5 & 1.8 \\
\hline Total land (ha) & 202 & 1.2 & 0.6 & 174 & 1.14 & & 376 & 1.2 & 0.5 \\
\hline Distance from market $(\mathrm{km})$ & 202 & 7.7 & 3 & 174 & 6 & & 376 & 7 & 3 \\
\hline
\end{tabular}

$\mathrm{N}=376$; source; own survey, 2019.

Table 3. Education level of respondents.

\begin{tabular}{lllllll}
\hline \multirow{2}{*}{$\begin{array}{l}\text { Educational } \\
\text { level }\end{array}$} & \multicolumn{2}{l}{ Kumruk } & \multicolumn{2}{c}{ Homosha } & \multicolumn{2}{c}{ Overall Average } \\
\cline { 2 - 7 } & $\mathbf{N}$ & $\mathbf{\%}$ & $\mathbf{N}$ & $\mathbf{\%}$ & $\mathbf{N}$ & $\mathbf{\%}$ \\
\hline Illiterate & 113 & 58.8 & 79 & 41.2 & 192 & 51.1 \\
Literate & 91 & 49.4 & 93 & 50.5 & 184 & 48.9 \\
\hline
\end{tabular}

$\mathrm{N}=376$; source; own survey, 2019.
Regarding the level of education, about $51.1 \%$ of the respondents were illiterate. As indicated in (table 3) out of this sample household head who are illiterate, $64.5 \%$ were male and the remaining $35.5 \%$ were female

Out of the total interviewed households in the district area of kuormuk and homosha $(\mathrm{N}=376) 55.5 \%$ is male-headed households and the remaining $44.5 \%$ were female headed 
households (Table 3).

Table 4. Sex of the respondent.

\begin{tabular}{lllllll}
\hline \multirow{2}{*}{ Var. } & \multicolumn{2}{l}{ Kumruk } & \multicolumn{2}{c}{ Homosha } & \multicolumn{2}{c}{ Overall Average } \\
\cline { 2 - 7 } & $\mathbf{N}$ & $\mathbf{\%}$ & $\mathbf{N}$ & $\mathbf{\%}$ & $\mathbf{N}$ & $\mathbf{\%}$ \\
\hline Male & 117 & 58 & 92 & 53 & 209 & 55.5 \\
Female & 85 & 42 & 82 & 47 & 167 & 44.5 \\
Total & 202 & 100 & 174 & 100 & 376 & 100 \\
\hline
\end{tabular}

$\mathrm{N}=376$; source; own survey, 2019.

Recently, among the modern agricultural institutions credit and extension services play an important role in facilitating agricultural development in general and livelihood diversification in particular. As most of the farmers are subsistence farmers and have had financial capacity constraint they are not able to buy and use farm modern inputs on their filed [17]. In the study areas, it was found that among the total respondents $51.9 \%$ of them used credit service offered for different agricultural purpose including purchasing farm input and other household income diversification activities. The remaining $48.1 \%$ of the household respondents did not use credit service.

Table 5. HHs used credit.

\begin{tabular}{lllll}
\hline Var. & Frequency & Percent & $\begin{array}{l}\text { Valid } \\
\text { Percent }\end{array}$ & $\begin{array}{l}\text { Cumulative } \\
\text { Percent }\end{array}$ \\
\hline No & 181 & 181 & 48.1 & 48.1 \\
Yes & 195 & 51.9 & 51.9 & 100.0 \\
Total & 376 & 100.0 & 100.0 & \\
\hline
\end{tabular}

$\mathrm{N}=376$; source; own survey, 2019.

Agricultural extension service in the study area offers various assistance in the form of technical advice such as provision of improved seeds, improved practices, close supervisions and frequent visit, training, provide technical information and access to new technology. The survey result showed about $73.1 \%$ of the respondents household used extension services through frequent contact with agricultural extension officer. Only about $26.9 \%$ of them had no frequent contact with the development agent.
Table 6. Extension service.

\begin{tabular}{llllll}
\hline Var. & & Frequency & Percent & $\begin{array}{l}\text { Valid } \\
\text { Percent }\end{array}$ & $\begin{array}{l}\text { Cumulative } \\
\text { Percent }\end{array}$ \\
\hline \multirow{3}{*}{ Valid } & no & 101 & 26.9 & 26.9 & 26.9 \\
& yes & 275 & 73.1 & 73.1 & 100.0 \\
& Total & 376 & 100.0 & 100.0 & \\
\hline
\end{tabular}

$\mathrm{N}=376$; source; own survey, 2019.

Remittance from relatives and diversification level

The survey result indicates that $13.8 \%$ of the sample households are having opportunity of receiving remittance and $86.2 \%$ of the sample households have not the chance.

Table 7. Household received remittance.

\begin{tabular}{llllll}
\hline Remittance & Frequency & Percent & $\begin{array}{l}\text { Valid } \\
\text { Percent }\end{array}$ & $\begin{array}{l}\text { Cumulative } \\
\text { Percent }\end{array}$ \\
\hline \multirow{2}{*}{ Valid } & no & 324 & 86.2 & 86.2 & 86.2 \\
& yes & 52 & 13.8 & 13.8 & 100.0 \\
& Total & 376 & 100.0 & 100.0 & \\
\hline
\end{tabular}

$\mathrm{N}=376$; source; own survey, 2019.

Participation in cooperatives and diversification level

In the study area, it was found that among the total respondents $49.7 \%$ of them participate in cooperatives the remaining $50.3 \%$ of the household respondents did not participate in cooperatives.

Table 8. Membership on cooperatives.

\begin{tabular}{llllll}
\hline Var & & Frequency & Percent & $\begin{array}{l}\text { Valid } \\
\text { Percent }\end{array}$ & $\begin{array}{l}\text { Cumulative } \\
\text { Percent }\end{array}$ \\
\hline \multirow{3}{*}{ Valid } & no & 189 & 50.3 & 50.3 & 50.3 \\
& yes & 187 & 49.7 & 49.7 & 100.0 \\
& Total & 376 & 100.0 & 100.0 & \\
\hline
\end{tabular}

$\mathrm{N}=376$; source; own survey, 2019.

\subsection{Livelihood Strategies and Diversity}

About $55.3 \%$ of the HHs heads have diversified their livelihood activities portfolio. And the remaining $44.7 \%$ of the HHs have not diversified (only practice agricultural activities).

Table 9. Livelihood diversification decision.

\begin{tabular}{llllll}
\hline Var & & Frequency & Percent & Valid Percent & Cumulative Percent \\
\hline \multirow{3}{*}{ Valid } & Non-diversified & 168 & 44.7 & 44.7 & 44.7 \\
& Diversified & 208 & 55.3 & 100.0 & 55.3 \\
& Total & 376 & 100.0 & 100.0 \\
\hline
\end{tabular}

$\mathrm{N}=376$; source; own survey, 2019.

To answer the question, what are the common means of livelihood beyond agriculture for rural households in the study area? We tried to identifying the common livelihood activities carried by each household in the study area beyond agriculture. The data were obtained directly from the diaries with no data processing, from experts. The common livelihood strategies/activities consist of gold mining, gun taping, sale of wood, trading of ox, trading of cash crops, coble stone work, small construction, traditional weaving, modern weaving, small business, selling local beer, copy machine, repair mobile phone, pool house, men barberry, female beauty salon, work in road construction, remittance from relatives etc. To reduce the complexity and have a better grouping, by considering the nature of the livelihood activities, we divide all these into five livelihood sectors, namely Trade, Construction, Manufacturing, Service, and 
employment. The majority $41.2 \%$ of HHs in the sample are participating in trade sector. The second most common participated sector is employment $(22.6 \%)$ and a small number of $\mathrm{HHs}$ conducted other sectors such as service $(17.3 \%)$, manufacturing $(6.6 \%)$, and construction (5.6\%). Therefore, the common means of livelihood beyond agriculture of the $\mathrm{HH}$ head in both the study areas is the trade sector. This is because the good accessibility of road between the kebeles.

Table 10. Percentage of HHs engaged in different sectors.

\begin{tabular}{ll}
\hline Type of activity & \% of HHs engaged \\
\hline Trade & 41.2 \\
Construction & 5.6 \\
Manufacturing & 6.6 \\
Service & 17.3 \\
Employment & 22.6 \\
\hline
\end{tabular}

$\mathrm{N}=376$; source; own survey, 2019.

Furthermore, livelihood diversification varies with the household's characteristics, such as number of productive family members, age, education level and gender. This similarity is due to the culture of the households, topography and their awareness regarding the importance of each sector.

Table 11. Sex of the respondent and livelihood diversification decision Cross tabulation.

\begin{tabular}{lllll}
\hline \multirow{2}{*}{ Var } & \multicolumn{2}{c}{ livelihood diversification decision } & \multirow{2}{*}{ Total } \\
\cline { 3 - 4 } & & Non- diversified & diversified & \\
\hline \multirow{2}{*}{ Sex } & Female & 46 & 58 & 104 \\
\multirow{2}{*}{ Total } & Male & 122 & 150 & 272 \\
\hline
\end{tabular}

$\mathrm{N}=376$; source; own survey, 2019.

\subsection{The Major Driving Forces to Livelihood Diversification}

The result of this analysis reveals that 49 percent of the respondents reported less land size as their first major driving forces for engaging in livelihood diversification, 19.2 percent considered less land productivity as their first or most driving forces, 15.9 percent reported less income as their first major driving forces and 6.7 percent reported food insecurity as their first major driving forces, and 4.8 percent reported natural problem (drought) as their first major driving forces and 4.3 percent reported unsustainable use of natural resources as their first major driving forces. The finding shows that the major driving forces why rural people engaged in livelihood diversified activities was less land size. This is because among the major driving forces for engaging in livelihood diversification, less land size had the highest score $(49 \%)$ as the first, against the other major driving forces for engaging in livelihood diversification.

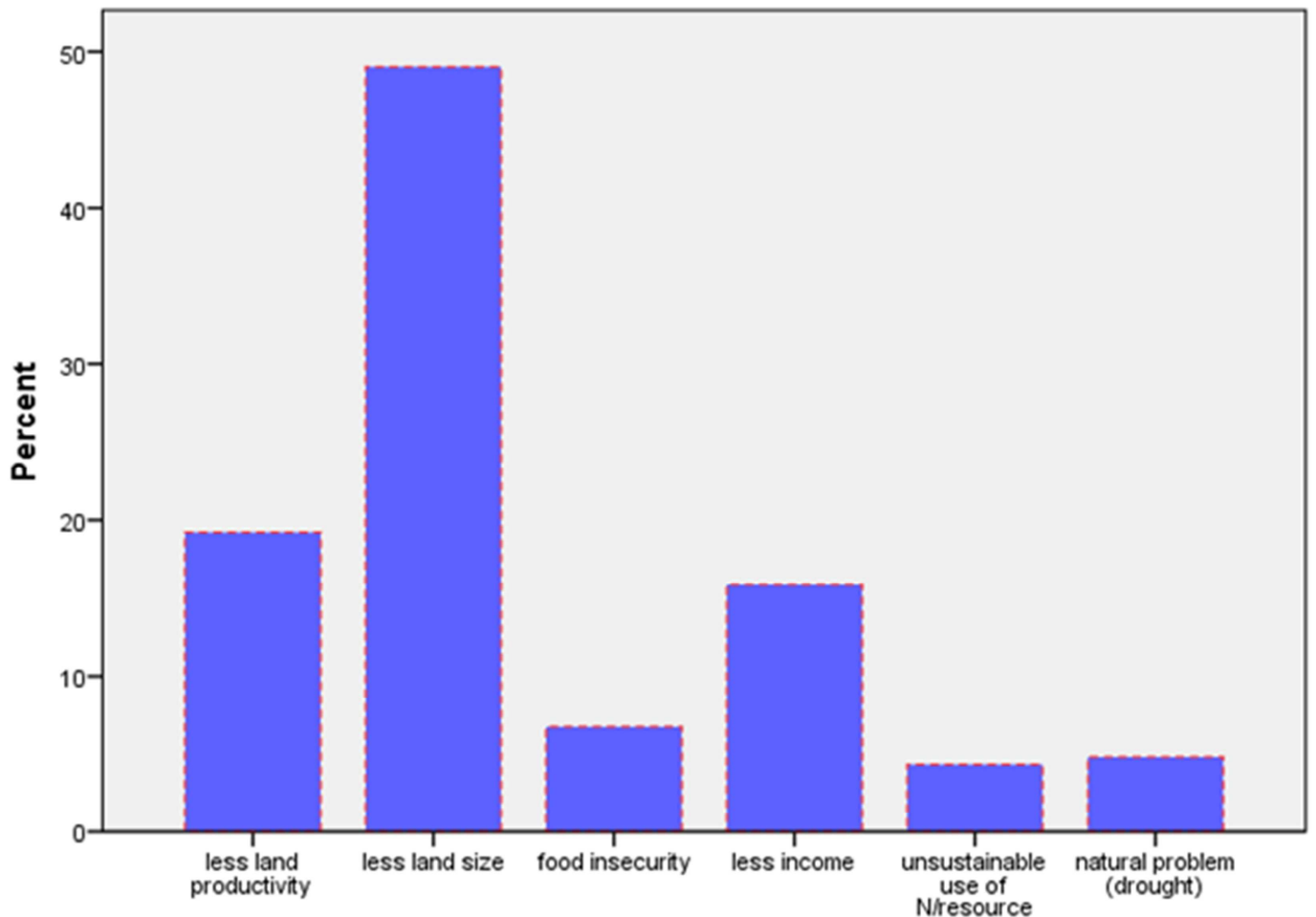

Figure 1. Major driving forces for engaging in livelihood diversification in both districts.

\subsection{Factors That Influenced Households Decision to Livelihood Diversifications}

\subsubsection{Binary Logistic Regression Analysis}

Binary logistic regression analysis was used to examine the effects of each independent variable on household's decision to livelihood diversifications, while controlling for other independent variables. Before proceeding to the analysis, model fitness is considered for livelihood diversification decision. 


\subsubsection{Goodness of Fit Test}

Goodness of fit test for the fitted binary logistic regression model is assessed using the Hosmer and Lemeshow test.
According, the Hosmer and lemeshow test for the model resulted in p-values of 0.477 , which tell us that the model adequately fit the data at 0.05 level of significant.

Table 12. Classification of livelihood diversification decision for binary responses.

Classification Table

\begin{tabular}{llllll}
\hline \multicolumn{2}{ll}{ Observed } & \multicolumn{3}{l}{ Predicted } & \\
\hline & & \multicolumn{2}{l}{ livelihood diversification decision } & \multirow{2}{*}{ Percentage Correct } \\
\cline { 3 - 5 } & & non- diversified & diversified & 72.0 \\
\multirow{2}{*}{ Step 1 } & livelihood diversification decision & Non- diversified & 103 & 40 & 82.9 \\
& Overall Percentage & diversified & 31 & 150 & 78.1 \\
\hline
\end{tabular}

The cut value is $.500 \mathrm{~N}=376$; source; own survey, 2019.

In addition to goodness- of fit test, we need to look at the classification table which tells us how many of the cases where the observed values of the dependent variable (livelihood diversification decision) are diversified or non- diversified have been correctly predicted. The result showed that $72 \%$ were correctly classified for non- diversified group and $82.9 \%$ for diversified group. Overall $78.1 \%$ were correctly classified.

\subsection{Model Estimation}

Table contains the significant variables, along with the estimated coefficients, standard errors of the estimate and pvalue. It also includes the odd ratios for ease of interpretation

K2 According to the Binary logistic regression result, out of 13 variables included in the model, 5 explanatory variables are found to be significant with respect to the likelihood of household's livelihood diversification decision. The variables are age of the respondent household heads, land size, getting training, access to credit services, receiving remittance.

Table 13. Parameters Estimates of the Binary Logistic Model.

\begin{tabular}{|c|c|c|c|c|c|c|c|c|c|}
\hline \multicolumn{10}{|c|}{ Variables in the Equation } \\
\hline & & \multirow{2}{*}{ B } & \multirow{2}{*}{ S. E. } & \multirow{2}{*}{ Wald } & \multirow{2}{*}{ df } & \multirow{2}{*}{ Sig. } & \multirow{2}{*}{$\operatorname{Exp}(B)$} & \multicolumn{2}{|c|}{ 95\% C. I. for EXP (B) } \\
\hline & & & & & & & & Lower & Upper \\
\hline \multirow{14}{*}{ Step $1^{\mathrm{a}}$} & Age & -.076 & .017 & 20.412 & 1 & .000 & .927 & .897 & .958 \\
\hline & $\operatorname{sex}(1)$ & -.495 & .381 & 1.687 & 1 & .194 & .610 & .289 & 1.286 \\
\hline & educs (1) & -.209 & .311 & .454 & 1 & .500 & .811 & .441 & 1.491 \\
\hline & Fsize & .024 & .154 & .023 & 1 & .878 & 1.024 & .758 & 1.384 \\
\hline & $\mathrm{Nfa}$ & -.250 & .195 & 1.632 & 1 & .201 & .779 & .531 & 1.143 \\
\hline & Time & -.003 & .003 & 1.185 & 1 & .276 & .997 & .992 & 1.002 \\
\hline & Tlu & -.153 & .079 & 3.779 & 1 & .052 & .858 & .735 & 1.001 \\
\hline & Lsize & -.791 & .301 & 6.885 & 1 & .009 & .453 & .251 & .819 \\
\hline & ex (1) & -.562 & .378 & 2.212 & 1 & .137 & .570 & .272 & 1.196 \\
\hline & training (1) & .970 & .412 & 5.539 & 1 & .019 & 2.637 & 1.176 & 5.915 \\
\hline & ceridt (1) & -1.351 & .313 & 18.613 & 1 & .000 & .259 & .140 & .478 \\
\hline & remit (1) & -1.307 & .476 & 7.525 & 1 & .006 & .271 & .106 & .689 \\
\hline & cooperative (1) & .286 & .313 & .836 & 1 & .361 & 1.331 & .721 & 2.458 \\
\hline & Constant & 7.347 & 1.060 & 47.994 & 1 & .000 & 1551.266 & & \\
\hline
\end{tabular}

a. Variable (s) entered on step 1: age, Sex, educs, fsize, nfa, time, tlu, lsize, ex, training, ceridt, remit, cooperative.

$\mathrm{N}=376$; source; own survey, 2019.

\section{Interpretation of econometric results}

Age of household head: the model shows that the age of respondent heads is a significant variable. The probability or odds of household decision on livelihood diversification are higher for younger households as compared to those older age households. The negative sign indicates that, as the household head age increase, the decision for livelihood diversification decrease. According to the model estimation, it is to mean that, a one unit increase in the age of respondent household head is found to have decrease odds of livelihood diversification by a factor of 0.927 and the result is statistically significant at $(\mathrm{p}<.000)$ (table 13) The possible reason is that farmers whose age is relatively younger, leaving other factors constant, could be pushed to engage more in non-farm activities than agriculture alone. This is because, younger farm households cannot get enough land to support their livelihood compared to the older farm households [18].

Land size owned (LAND): As hypothesized, the area of land owned by the household has a significant $(\mathrm{P}<0.05$ and $\mathrm{p}<0.10$ ) and negative correlation with the likelihood of household's decision on livelihood diversification. The results of this study suggest that rural households with more land tend to follow agricultural extensification rather than diversifying from agriculture since they draw incentives of land productivity. It is to mean that, a one unit increase in the 
farm size is found to have decrease odds of livelihood diversification by a factor of 0.453 and the result is statistically significant at $(\mathrm{p}<.000)($ table 13$)$ On the other hand the probability of diversifying livelihoods decreases by increasing land size as farmers with more land supposed to stay on farm since land stimulates farming. It also implies that those households who expect secured agricultural income stay on farm and lower off-farm intensity. [19] also found out that landholdings per capita are negatively correlated with participation in low productivity occupations [20].

Credit use (CREDIT): credit use is found to have a significant $(p<0.05)$ negative impact on the likelihood of choosing diversified livelihood strategy. This implies that, the likelihood of participating in diversified livelihood strategy by the household drops by 0.259 for a household using credit. This negative impact may be attributed to the fact that credit use allows farmers to follow agricultural intensification by accessing farm inputs which in turn improves productivity. This more implies that the formal and informal credit facilities that avail for rural farmers are a very important asset in rural livelihoods not only to finance agricultural inputs activities, but also to protect loss of crucial livelihood assets such as cattle due to seasonal food shortage, illness or death [21]. The result of the study, therefore, strongly suggest that farmers' access and use of credit would play important role in promoting agricultural development rather than diversification. This implies that the incentive for accessing credit accelerates agricultural production [22].

Receiving remittance (REMITA): remittance refers to money sent from inside and outside the country. The binary logit model identified this variable as it had negative contribution to the diversification of livelihood strategies, at significance of $<10 \%$ probability level. This meant that, the likelihood of a household receiving remittance decrease choice of diversification by 0.271 . This negative impact may be attributed to the fact that households use this for their basic necessities, this implies that receiving remittance would help to fulfill their basic necessities and cope in case of shocks and important for keeping rural households diversify activities.

Training:-This variable has a positive and significant $(p<0.10)$ correlation with the likelihood of choosing farm and non- farm livelihood strategy instead of sustaining on agriculture alone. Keeping other factors constant; the likelihood of participation in livelihood diversification increases by 2.637 for those who have gained training than the counterparts. The objectives of training is to change farmers outlook towards their difficulties which assists them adapt better solution to their livelihoods [23].

Thus, the training obtained and the knowledge and skill gained from training may influence farmers' skill and decision making on seeking diversification. Most of the nonfarm activities being skill based, training increases the possibility of getting nonfarm jobs. Therefore, a positive relationship were found between livelihood diversification and training.

\section{Conclusions and Recommendations}

\subsection{Conclusions}

Based on the findings from the study, the following conclusions are given:

Livelihood diversification is a process followed by the households in the study areas. The study reveal that livelihood diversification is high in both the study areas however, current livelihoods seem not sufficient to provide security and it varies with location. Hence, instead of replacing farm activities with other income generating activities, it is better to promote strategies that support the diversification process. Livelihood enhancement activities which are based on the available asset should be promoted. It was found that trade sector is a highly diversified sector in term of the number of households participating and is considered to be the most important source of livelihood besides farming. Thus promotion of such marketing activities should be promoted. Thus concerned regional governments, NGO and other parties should promote livelihood enhancement activities. The result of the binary logistic regression revealed that out of 13 variables included in the model, 5 explanatory variables are found to be significant up to less than $10 \%$ probability level. Accordingly, age of the household head, access to credit, receiving remittance and land size have negative association with livelihood diversification strategy. Whereas, getting training has a positively influence on households choice of livelihood diversification.

\subsection{Recommendations}

Household livelihoods are highly diverse in both districts. Policy-makers need to reflect on the most suitable ways of supporting this diversity. Any attempt to intervene the community need to target specific groups of societies such as female headed households, wage workers, petty traders, and the poor. The intervention strategy should have a needs identification to address both the basic needs as well as the needs that arise from wealth category specific constraints.

The policy to promote adoption of credit to stimulate livelihood diversification has not been very successful in the study areas. Farmers were reporting that they failed due to the case UN periodic credit dispersement. Credit service is essential to improve both agricultural and non-agricultural production. In addition, improving production is a center of the current development strategy. Hence, increasing credit access and strengthening the credit institutional arrangement is much advisable to make this development possible and improve livelihoods of rural households.

Receiving remittance refers to money sent from inside and outside the country. Although remittances constitute only a small part of total household about $13.8 \%$ income on average, they appear not important for keeping rural households diversify activities. In fact, receiving remittance increase choice of diversification into off farm and nonfarm activities. So awareness must be created by different stakeholders. 
Frequency of contact of extension agents for training and advice of farm households should also be emphasized, since it has significant effect for farmers on creating different livelihood activities.

The findings from the respondents and the FGD report point to the fact that the area is facing serious vulnerability beyond their capacity and thus living in an unsustainable livelihoods. In line with the view of Bohle et al (1994) the prescriptive and normative response to vulnerability is to reduce exposure, enhance coping capacity, strengthen recovery potentiality and bolster damage control (i.e. minimize destructive consequences) via private and public means.

Based on the present study it is possible to conclude that the constraints of the rural households in choosing livelihood strategies that will lead them achieve food security goal should not be put aside since food security problem cannot be overcome by simply concentrating on the farm sector alone; inter sectorial issues and farm and non-farm linkages need to be addressed as well. Moreover, the contribution made by non-agricultural sector to rural households is a significant; although for the poor these activities are survival oriented and have little to do with wealth accumulation.

\section{References}

[1] Adugna, E. (2005). Livelihood strategies and food security in Wolayta, Southern Ethiopia: The case of Boloso Sore district. A Thesis is submitted to the School of Graduate Studies, Haramaya University.

[2] Adugna Lemi, (2005). The Dynamics of Livelihood Diversification in Ethiopia Revisited: Evidence from Panel Data, Department of Economics University of Massachusetts, Boston.

[3] Cochran, W. G. (1977). Sampling Techniques, 2nd Ed., New York: John Wiley and Sons, Inc.

[4] CSA (Central Statistical Authority). (2007). population and housing census of Ethiopia.

[5] CSA (Central Statistical Agency), 2018. Key Findings of the 2017/2018: Agricultural Sample Surveys.

[6] Canagarajah, S., Newman, C. and Bhattamishra, R. 2001. Non-Farm Income, Gender and Inequality: Evidence from Rural Ghana and Uganda. Food Policy 26 (4) 405-420.

[7] DFID (Department for International Development), 2000. Sustainable Rural Livelihoods Guidance Sheet, London, UK.

[8] Destaw Berhanu, 2003. Non-farm Employment and Farm Production of small holder Farmers: A Study in Edja District of Ethiopia. A Thesis Submitted to the School of Graduate Studies Alemaya University.

[9] Ellis, F. 1999. Rural Livelihood diversity in Developing Countries: Evidence and Policy Implications. Overseas Development Institute.

[10] Ellis, F. (2000). Rural Livelihoods and Diversity in Developing Countries. Oxford: Oxford University Press.

[11] Ellis, F. (1998). Household strategies and rural livelihood diversification. Journal of Development Studies, 35, 1-38. doi: $10.1080 / 00220389808422553$.

[12] IIRR. 2004. Food Security in Pastoralist Areas of Ethiopia. International Institute of Rural Reconstruction. Nairobi, Kenya.

[13] Loison, S. A., \& Loison, S. A. (2016). Rural livelihood diversification in Sub-Saharan Africa: A literature review. The Journal of Development Studies, 51, 1125-1138. doi: 10.1080/00220388.2015.1046445.

[14] Nyambara, P. S., 2003. Rural Landlords, Rural Tenants, and the Sharecropping Complex in Gokwe, Northwestern Zimbabwe, 1980- 2002. University of Zimbabwe, Centre for Applied Social Sciences. Obasi, G. O. P., 1994. WMO's role in the international decade for natural disaster reduction. Bull. Am. Meteorol. Soc. 75 (9), 1655-1661.

[15] Readon, T. (1997). Using evidence of household of income diversification to inform study of rural non-farm labor market in African: World Development, vol 25, No: 735-47.

[16] Reardon, T., Delgado, C. and Malton, P. (1998). Determinants and Effects of Income Diversification amongstFarm Households in Burkina Faso. Journal of Development Studies, Vol. 28 (2).

[17] Smith, D. R., Gordon., A, Meadows., K, Zwick., K. (2001). Livelihood diversification in Uganda: patterns and determinants of change across Mtwo rural districts, Food Policy 26.

[18] Saha, B., \& Bahal, R. (2012). Constraints impeding livelihood diversification of farmers in West Bengal. Indian Research Journal of Extension Education, 12, 59-63.

[19] Tesfaye Lemma, 2003. Diversity in livelihoods and farmers strategies in Hararghe highlands, Eastern Ethiopia, University of Pretoria, South Africa.

[20] Woldehanna, T. \& Oskam, A. 2001. Income Diversification and Entry Barriers: Evidence from the Tigray Region of Northern Ethiopia. Food Policy 26 (4): 351-365.

[21] Wassie Berhanu. 2005. Pastoralism and Livelihood Diversification: A Case Study of the Borana Pastoral System in Ethiopia, A Ph. D. Thesis Submitted for the University of Manchester. 